\title{
Conceptualization and representation of the passing of time in Spanish phraseology: A gender study
}

\author{
Enrique Gutiérrez Rubio* \\ Palacky University Olomouc, Czech Republic
}

\begin{abstract}
According to the cognitive linguistics approach to phraseology, the majority of idioms are not linguistic but conceptual in nature. Moreover, they have to be seen mainly as a cultural product and, consequently, they are a splendid device for revealing the values of a given society. The aim of this study is to reveal the notion of the passing of time, as it is differently conceptualized for women and men in Spanish phraseology. Additionally, their dissimilar representations via linear structures based on the TIME IS SPACE conceptual metaphor will be proposed. The main conclusion of the study is that, according to Spanish idioms, men's lives can be represented by a single-line structure divided into two opposite, isolated periods - childhood and maturity. On the contrary, women's linear representation looks more like a continuous line that becomes a "forked" path a short time after women leave childhood behind. Finally, the relationship between the contemporary functioning of PUs and the endurance of the etymological stereotypes underlying these expressions will be considered.
\end{abstract}

\section{Key words}

time, phraseology, gender, timelines, conceptual metaphor

\section{Introduction}

Since the publication of the seminal work on gender and language by Robin Lakoff (1973), almost all levels of language - from phonetics and phonology to morphology, lexicon and syntax and all the way through to pragmatics and discourse - have been intensively analysed and discussed from a gender perspective (Eckert and McConnell-Ginet, 2013, pp. 66-79). Nevertheless, scholars devoted to language within gender studies and the feminist movement have not so far accomplished an extensive analysis of gender in phraseology. By using a cognitively oriented approach to the study of phraseology - as proposed mainly by Dobrovol'skij and Piirainen (2005a) - this could be changed, especially if it is taken into account that phraseological units (PUs) have to be seen mainly as a cultural product and, consequently, can be used as a direct and fruitful device for revealing the cultural and social values of a given group, including, of course, the way language echoes the gendered asymmetry of society. Moreover, the TIME IS SPACE conceptual metaphor (Lakoff and Johnson, 2003 [1980]; 1999; Lakoff, 2006 [1993]) explains how humans organize and comprehend a non-spatial concept such as time. In this sense, the representation of time in terms of linear structures, e.g. timelines (Coulson and Pagán Cánovas, 2014), can be a useful cognitive device for gaining a better understanding of temporal events. The aim of this study is to reveal the notion of the passing of time as it is conceptualized in two different ways for women and men in Spanish phraseology. Additionally, their representations via linear structures will be proposed. Finally, a corpus analysis will be conducted in order to shed light on the

\footnotetext{
*Address for correspondence: Enrique Gutiérrez Rubio, Department of Romance Languages, Faculty of Arts, Palacky University Olomouc, Kř́žkovského 10, $771 \quad 80$ Olomouc, Czech Republic. E-mail: enrique.gutierrez@upol.cz
} 
present-day functioning of those Spanish PUs which are clearly underpinned by male and female conceptualizations of the passing of time, understood as the contrast between childhood and adulthood.

\section{Gender studies and phraseology}

According to the basic principles of gender studies, a clear distinction has to be made between sex and gender. The term sex refers to a biological categorization and it is a binary concept - male or female. On the contrary, gender is a cultural construct. It is something we do or perform (our actions and behaviours), and not something we have. Obviously, gender is based on biology but, as Eckert and McConnell-Ginet (2013) assert, "[...] it does not flow naturally and directly from our bodies. The individual's chromosomes, hormones, genitalia, and secondary sex characteristics do not determine occupation, gait, or use of color terminology" (p. 5.). So, gender is socially and culturally constructed on the basis of the magnification of the biological differences between men and women. Moreover, this clear (almost radical) division of all persons into two different groups permeates almost every aspect of society: "Whether we identify as a man or as woman determines how we look, how we talk, what we eat and drink, what we wear, our leisure activities, what jobs we do, how our time is deployed, how other people relate to us" (Bradley, 2013, p. 6). A last question has to be raised in this brief introduction to gender studies and, namely, that these gender differences are not equally developed in all societies; on the contrary, in the Western (including Spanish) patriarchal society the features associated with male stereotypes and values are, almost without exception, evaluated more positively than the female ones (see Martín Casares, 2012, p. 43).

Unlike other levels of language, scholars have not yet paid enough attention to the way phraseology echoes the gendered asymmetry of society. This fact is probably due to the lack of an established tradition of studies of phraseology in the Anglo-Saxon world, where gender studies have mainly been developed. Moreover, those countries and regions where phraseology has been richly developed for decades - such as the former Soviet Union, Poland and Czechoslovakia - did not focus on gender studies until recent times. ${ }^{1}$ Moreover, studies of phraseology have been undergoing a revolution since the last years of the 20th century. As a result of this, phraseology is no longer considered a minor, marginal field - almost a linguistic deviation or abnormality (see Naciscione, 2010, p. 22) - but a central, living and creative linguistic discipline (see Luque Nadal, 2012, p. 9). This recognition has led to the development of new possibilities in the studies of phraseology, including the cognitively oriented approach, according to which the majority of PUs are not linguistic but conceptual in nature. So, as Kövecses (2002, p. 233) affirms: "An idiom is not just an expression that has a meaning that is somehow special in relation to the meanings of its constituting parts, but it arises from our more general knowledge of the world embodied in our conceptual system." In the same vein, Dobrovol'skij and Piirainen state that a specific conceptual structure is to be found in the meaning of most PUs, a conceptual structure that "[...] is based on mental imagery, and it provides an element of the content plane of a given figurative unit, which we call image component" (2005a, p. 5).

Finally, the shortage of works addressing phraseology and gender is of great importance given that, unlike other elements of language, PUs can be taken as a highly explicit and direct device for revealing the cultural and social values of a given group. In this sense, Dobrovol'skij and Piirainen (2005a) state that idioms "record and preserve relevant knowledge as part of their content plane (as image traces), including, above all, reflection of the respective culture" (p. 1). Accordingly, phraseology can be used as a rich source of information about the way a given society perceives and conceptualizes abstract notions such as gender asymmetries.

\section{Conceptual metaphors and visual representations of time}

The fundamentals of conceptual metaphor theory (CMT) were proposed as early as 1980 by Lakoff and Johnson in Metaphors We Live By. According to them, "most of our ordinary conceptual system is metaphorical in nature" (2003 [1980], p. 4). In other words, metaphor is not a specifically linguistic mechanism but a general cognitive one. In this seminal work, the spatialization of time is already

\footnotetext{
${ }^{1}$ Partial studies can be found in Teliya (1996, pp. 260-269), Piirainen (2007, p. 217; 2008, p. 213), Dobrovol'skij and Piirainen (2010), and Kedron (2014), among a few others.
} 
discussed in some detail via the conceptual metaphor TIME IS A MOVING OBJECT, by virtue of which in English "[...] time receives a front-back orientation facing in the direction of motion, just as any moving object would" (2003 [1980], p. 42). Later on, Lakoff (2006 [1993]) goes into more detail about the way time is normally comprehended by means of metaphor and conceptualized in terms of space, in this case expressed via the conceptual metaphor TIME PASSING IS MOTION. In Philosophy in the Flesh Lakoff and Johnson devote a whole chapter to their concept of time and its metaphorical mappings between conceptual domains (1999, pp. 137-169). Here the authors delve into this issue and include new considerations about time as a cognitive mechanism in languages other than English or about the role played by the Space-Time metonymies, among others.

As has been observed, CMT seems to explain sufficiently how humans organize and comprehend a non-spatial concept such as time. However, authors following conceptual integration theory (CIT) argue that such mappings between two domains are too simplistic an explanation of such a complex cognitive phenomenon and that conceptual integration, i.e. a higher-order operation for combining information, has to be taken into account. Consequently, Fauconnier and Turner argue that "[the] conceptual correspondence between time [...] and physical space [...] is a final product of emergent structure in the elaborate integration network, not something to postulate as a basic primitive of human understanding" (2008, p. 61). In the same vein, Pagán Cánovas, Valenzuela and Santiago (2015) provide experimental evidence suggesting the validity of the blending hypothesis regarding the conceptualization of time.

Additionally, visual representations of time are mostly based on the TIME IS SPACE conceptual metaphor. In this sense, linear structures can be a useful cognitive device for gaining a better understanding of temporal events. In general, they are oriented horizontally and from left to right, following the general spatialized conceptualization of time in Western society. However, many other ways of depicting time in terms of space are possible.

In our time, the most common and widespread visual representation of time is through timelines. Coulson and Pagán Cánovas define a timeline as an "information visualization tool for communicating a sequence of related events [in which] [v]erbal descriptions of events are arranged chronologically, displayed on a line oriented either horizontally or vertically" (2014, p. 200). Although we could think of this as a simple (almost obvious) way of representing time graphically, it was introduced for the first time by Joseph Priestley as late as the second half of the eighteenth century, in the Chart of Biography, first published in 1765 (see Grafton and Rosenberg, 2010, pp. 19ff.).

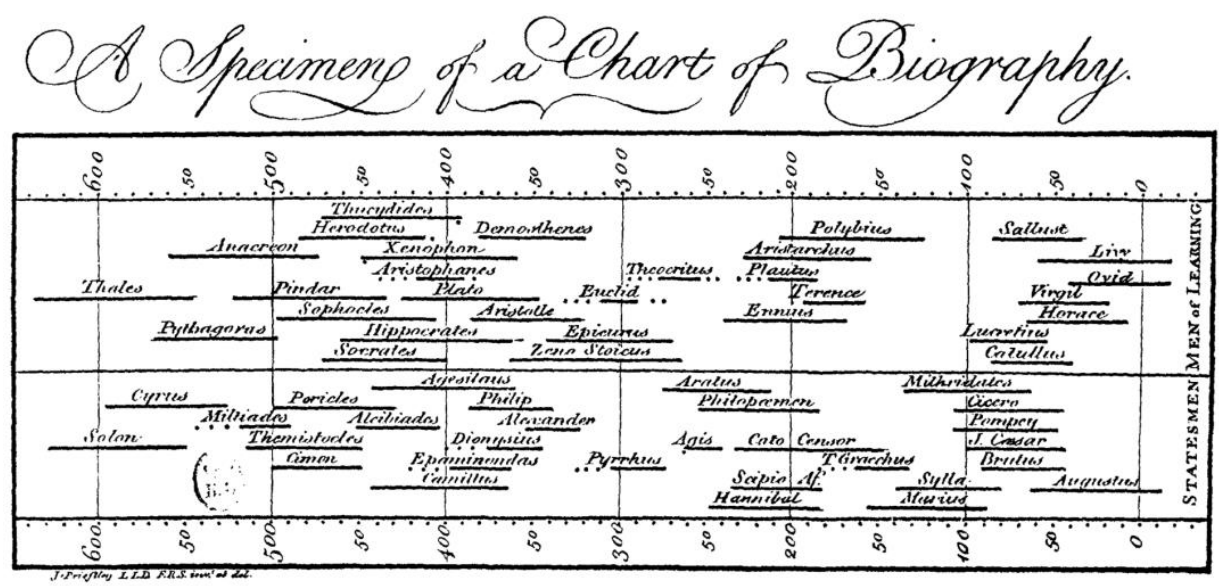

Figure 1. Priestley's Chart of Biography, 1765

In fact, more fundamental conceptualizations such as number-to-line mappings or number lines were not explicitly characterized in Europe until the 17th century, and at that time solely in the works of a few pioneering mathematicians, such as John Napier and John Wallis (see Núñez 2011, pp. 655-657). 


\section{Men, women and the passing of time in Spanish phraseology \\ 4.1 Methodology of the study}

For comprehensive research on the gender stereotypes underlying Spanish phraseology (see Gutiérrez Rubio, 2016), 407 phraseological units (PUs) were systematically analysed (see Appendix 1 for the complete set of PUs in alphabetical order). These are all the expressions related to male or female characteristics and stereotypes documented in Diccionario fraseológico documentado del español actual: locuciones y modismos españoles, the most up-to-date dictionary of Spanish phraseology (Seco et al., 2004). In order to analyse them more effectively, these PUs were split into five main thematic categories: 1) physical characteristics; 2) attitude, personality and abilities; 3) sexuality; 4) family; 5) activities and professions. However, a last, transversal category was added, since it turned out to be one of the most interesting findings emerging from this research on Spanish phraseology - the divergent male and female conceptualizations of the passing of time.

The methodology of this study was based on the research possibilities provided by the cognitive linguistics approach to phraseology and structured on three levels of specificity.

On the first level, Conceptual Stereotypes in Focus (CSFs) were taken into account. What is meant by a CSF is a generalized conceptualization or stereotype in a given society that has become phraseologized as a result of a figurative process. This activation of stereotyped characteristics by means of conceptual focusing is based on the more general cognitive theories of profiling by Langacker (2006). For instance, the widespread stereotype that men are (both physically and mentally) stronger than women clearly underlies the Spanish PU Sexo débil (just the same as its English counterpart Weaker sex). Another example would be Mujer de la casa (lit. "woman of the house"), an expression that gathers some of the stereotypes associated with the role of women as housewives. Naturally, it is not argued that every widespread stereotype automatically implements an associated PU. It is only claimed than the very foundation of the process of phraseologization often relies on generalized conceptualizations shared by a significant portion of the society. For instance, the stereotype referring to the supposed inability of women to drive cars properly has not activated any PU in Spanish such as *Bad driving sex or the like.

On a second level of specificity, the concept of a Frame proposed by Fillmore (2006) was used. Fillmore defines a Frame as "[...] any system of concepts related in such a way that to understand any one of them you have to understand the whole structure in which it fits" (p. 373). In its application to the study of phraseology, Dobrovol'skij and Piirainen (2009, pp. 24-25) stress the importance of analysing not just the explicit elements of PUs, but also their implicit constituents. These authors illustrate it with a German PU with Spanish cultural motivation: Ein rotes Tuch für jmdn sein 'to provoke someone' (lit. "to be a red rag [to a bull] for someone", similar to English Sthg acted like a red rag to a bull). The image component of this PU can easily be inferred when examining it within the frame bullfighting. This frame includes some other implicit elements (called slots) such as bullfighter or bull that provide the PU with its lexicalized metaphoric semantics. By applying this approach to the specific topic of this paper, a PU such as Hijo/niño de papá, 'someone living at the expense of his/her well-off father' (lit. "Daddy's son/boy"), implicitly refers to the frame patriarchal family, in which the father is the head of the family and the only person who has financial resources at his disposal. A feminine version of this PU with "mother", *Hijo/niño de mamá, has not been conventionalized in Spanish, probably since children stereotypically do not live at the expense of their mothers, for the simple reason that in the (recent) past most women lacked proper incomes.

The third and lower level of specificity provides less conclusive data. In this case, it is not possible to extract any CSFs or to analyse frames implicitly present in the PUs. For this level, non-figurative elements of the lexical form are taken into account. This sort of analysis is especially productive when considering activities and professions that have been performed through the centuries exclusively by men or by women. For instance, although at present both women and men practise legal professions, all the documented PUs with the lexical form abogado, 'lawyer, advocate', are male-specific: Abogado de causas perdidas, Abogado de secano, and Abogado del Diablo. Consequently, it can be concluded that this occupation was historically segregated by sex.

As already mentioned, in this study it is assumed that the gender stereotypes present in Spanish phraseology will, at least partially, reflect the speakers' conceptual system and values regarding men and women. Therefore, it is necessary to characterize what a gender stereotype is and which are the most common ones in Western culture, to which Spanish society belongs. According to Eckert and McConnell-Ginet: 
[Stereotypes] serve as a kind of organizing device in society, an ideological map, setting out the range of possibilities within which we place ourselves and assess others. They are means for constructing and highlighting social categories, whether for positive or negative purposes. For this reason, stereotypes, and their relation to behavior, are central to the study of language and gender [...] stereotypes typically constitute norms - often rather extreme norms - that we do not obey, but that we orient to. As such, they provide us with crucial information about the ideological landscape in which language unfolds. (Eckert and McConnell-Ginet, 2013, pp. 58-59)

Further, only 20 of the original 407 PUs were chosen for the analysis presented in this paper. Obviously, this selection was not arbitrary - the criterion that was used for opting for these 20 specific expressions was that they are the only Spanish PUs documented in Seco et al. (2004) which are clearly underpinned by male and female conceptualizations of the passing of time, understood as the contrast between childhood and adulthood. Moreover, all these PUs need to have a clear idiomatic component ${ }^{2}$ to denote additional naming (see Dobrovol'skij and Piirainen, 2005a, p. 18) and to be easily evaluated as positive or negative. All neutral expressions, together with those that, although lexicalized, are not figurative, were discarded from the study, including PUs such as Niño de pañales (lit. "little boy of diapers", according to the definition by Seco et al. (2004), roughly 'little baby') or Niño de pecho (lit. "little boy of breast", roughly 'breastfed baby').

Since the majority of PUs refer to adult men and women, the only 10 idioms that explicitly include the words niño, 'little boy' (see PUs 1-9), and niña, 'little girl' (see PU 14), and that fulfil the requirements mentioned above were analysed. The remaining 10 expressions are the only idiomatic and evaluative PUs documented in the dictionary associated with situations, events or characteristics distinctive to the passing from childhood to adulthood of every man/woman - physical features of being adult (see PUs 10-12), the very process of becoming adult (PUs 13, 15, and 16), and the possible consequences of this process (PUs 17-20). The remaining PUs from the comprehensive research, almost 400 in number, cannot be directly associated with this passing from infancy to maturity. Let us take as an example the activities and professions performed by men or by women. Undoubtedly, they tell us much about the secondary role played by women during history; however, this group of PUs, all of them related to adult life, does not reveal much about the passing of time as such, since they cannot be related to every person, but just to those people performing the activity in question. In other words, when the time comes, hair grows on every man's body and all women reach "the age of merit", but different men and women practise diverse professions.

Besides, it is important to clarify that the dictionary of Spanish phraseology by Seco et al. (2004) gathers exclusively PUs used in Spain, not in Spanish America. In addition, this work is up-to-date and documented, what means that all the PUs are illustrated with examples excerpted from Spanish texts dated between 1955 and 2004. In consequence, the findings of the analysis will refer solely to the conceptualization of the passing of time that is (to a greater or lesser extent) alive in contemporary Spanish society, as will be discussed later.

\subsection{Results of the analysis}

After examining the excerpted PUs, it can, in the main, be claimed that no significant differences are observed regarding the ways men and women are born and die. On the other hand, some features of their childhood and maturity are conceptualized in two opposite manners.

If we start with PUs related to males, a negative association is clearly evident with regard to children. Six out of nine PUs including the word niño, 'little boy', are marked in Seco et al. (2004) as despectivo, 'derogatory' (PUs 1-6). Moreover, even though this is not explicitly expressed by the authors, all of them conceptualize children in a negative manner (the only partial exception is PU 8, as will be discussed later).

\footnotetext{
${ }^{2}$ Although it is unquestionable that Seco et al. (2004) is the best dictionary of Spanish phraseology published so far, Penadés Martínez (2015, pp. 80ff.) rightly criticizes a certain lack of systematicity in this sense.
} 
(1) Niño/hijo de papá - lit. "daddy's little boy/son", roughly 'person who lives at the expense of a wealthy father'.

(2) Niño de Serrano - lit. "little boy from Serrano [street]", roughly 'rich and snobbish young person'.

(3) Niño gótico - lit. "little gothic boy”, roughly 'arrogant, unsubstantial young man'.

(4) Niño pitongo/bitongo - the words pitongo and bitongo have no clear meaning in Spanish and are used only in this expression, roughly 'prudish and boastful young person'.

(5) Niño zangolotino - lit. "childish little boy", roughly 'young man whose behaviour and mentality are still typical of a little boy'.

(6) Niño bonito - lit. "pretty little boy", roughly 'rich and arrogant young man'.

(7) Niño litri - the word litri has no clear meaning in Spanish and is used only in this expression, roughly 'snooty or arrogant person'.

(8) Niño mimado - lit. "spoilt little boy", roughly 'a person who is somehow favoured'.

(9) Ser (como) un niño - lit. "to be (like) a little boy", roughly "to display childish immature behaviour'.

On the contrary, adult men are conceptualized in a positive way as full men. This second stage of men's life is symbolized in Spanish phraseology by the presence of hair on their face, chest, and genitalia. This clearly contrasts with the smooth skin of non-full men, i.e. male children:

(10) De pelo en pecho - lit. "of hair on chest", roughly 'determined and brave person'.

(11) Tener pelos en los cojones (o en los huevos) - lit. "to have hairs on the bollocks (or on the eggs)", roughly 'to be an adult and brave man'.

(12) Con toda la barba - lit. "with all the beard", roughly 'man at the peak of his qualities'.

The advantages of growing from an immature boy to a full man can also be observed in (13) Hacer un hombre (lit. "to make [someone] a man", roughly 'to provide a great benefit to someone').

Contrary to this, only one PU is documented in relation to female children: (14) La niña de sus ojos (lit. "the little girl of his/her eyes", roughly 'to show affection or esteem to someone or something'). This divergence in the evaluation of male and female children could be explained by the fact that, unlike their male counterparts, the qualities of little girls and young adult women in our society are not in contradiction - both are stereotypically beautiful, fine, sensitive and small, but can also be spoilt, immature, and dependent on a man, either their father or husband. ${ }^{3}$ On the contrary, all these characteristics are unacceptable for adult men. In other words, whilst real men need to evolve and mature, leaving their effeminate childhood behind, women follow a sort of continuous path from childhood into adulthood.

Nevertheless, as soon as little girls become young women their role in society changes all of a sudden. The first stage could be called being of marriageable age, reflected in two very similar PUs:

\footnotetext{
${ }^{3}$ These and other stereotypes referred to in the discussions of this paper do not emerge from the author's own knowledge or intuition, but from an inventory of Western stereotypes collected for this study and mainly based on gender oppositions excerpted from works written within the framework of gender and feminist studies such as Bradley (2013), Collier (2004), Connell (2005; 2009), Doka and Martin (2010), Eckert and McConnell-Ginet (2013), García Mouton (2010), Kedron (2014), Kimmel (2011), Lakoff (1973), Martín Casares (2012), Mills (2008), Oakley (2005), and Talbot (2010).
} 
(15) Edad de merecer (lit. "age of merit") and (16) (En) estado de merecer (lit. "(in) state of merit"), both roughly 'the right age and circumstances to start an engagement'. This potential capacity soon becomes an urgent necessity, so that young women are pressured by their family and society to find a husband. Once married, women are stereotypically able to fulfil their main task in adult life as wives, mothers and homemakers. Otherwise, they end up alone and useless to society, as can be observed in the expressive image components of PUs (17), (18), and (19).

(17) Pasársele el arroz (a una mujer) - lit. "to overcook the rice (to a woman)", roughly 'to be too late to get married'.

(18) Quedarse (una mujer) para vestir santos/imágenes - lit. "to be left (a woman) for dressing [statues of] saints", roughly 'to stay definitively single'.

(19) Irse al poyetón / quedarse en el poyetón (una mujer) - lit. "to go / to stay on the stone bench (a woman)", roughly 'to stay single'.

These last three Spanish PUs speak convincingly of the stereotypical necessity of women to find a husband while they are still young (and attractive); otherwise, they are doomed to spend the rest of their lives without a meaningful duty. In fact, one of the worst things that can happen to a young woman is to be left shortly before her wedding, as is recorded in Spanish PU (20) Compuesta y sin novio (lit. "ready and without a groom", roughly "not to get something you were expecting after making all the necessary preparations for it').

Naturally, those women who do get married still have to get pregnant, give birth to children, and breastfeed and rear them in order to become full women. Some of these activities are reflected in a series of PUs that were discarded from the study because of their neutral evaluation or their lack of idiomaticity, such as Hacer un hijo (a una mujer) (lit. "to make a child (to a woman)", roughly 'to get her pregnant') or Criar (una mujer a alguien) a sus pechos (lit. "to rear (a woman someone) at her breasts", roughly 'to breastfeed or raise someone').

Now the question arises of what the real significance of these 20 expressions is and to what extent it can be stated that they actually characterize the conceptualization of men and women in our society. First of all, it has to be admitted that we are dealing here with a low number of PUs and that logically only tendencies and not firm statements can be proposed. However, following Dobrovol'skij and Piirainen (2005a), PUs record relevant knowledge about societies and, logically, can be successfully used for revealing cultural and social values, even when working with limited and problematic linguistic material. Moreover, as already stated, only European standard Spanish is taken into account - American Spanish and any regional variants within Spain were excluded from the study. Besides, as observed and discussed by Dobrovol'skij and Piirainen (2010), although the etymology of an idiom can affect its contemporary functioning, it is not accurate to equate the motivation of an idiom with its real use. According to this, it is necessary to check whether the 20 PUs in the present study are or are not genderspecific in their origin and in their current use. This issue seems to be especially relevant when examining the PUs with "niño", given that, according to Seco et al. (2004), all the PUs including the word niño can also be used, although in their feminine versions, using the word niña. Moreover, Seco et al. (2004) propose a masculine version of PU (20): Compuesto y sin novia. Nevertheless, the etymology of this last PU is without a doubt based on a female stereotype, as can be observed in a longer form of this expression collected by Cantera Ortiz de Urbina (2011, p. 232): Como la novia de la Rota, aderezada/compuesta y sin novio (lit. "like the bride from Rota, dressed up/ready and without a groom"). Besides, after consulting three dictionaries devoted to the origin and motivation of Spanish idioms (Doval, 2010; García Remiro, 2013; Iribarren, 2013) only one of the 20 PUs was documented. Both Doval and García Remiro believe that La niña de sus ojos recalls a metaphor based on the Greek word kóre, which meant both little girl and the pupil of the eye. Moreover, pupila in Spanish can denote both this valuable part of the eye and an orphaned little girl. So, it is possible that the origin of this PU is more complicated than one might think at first sight but, one way or another, the concept little girl is present in it. 
Since the remaining PUs considered in this work seem to have a very transparent etymology, for this study it is assumed that the motivation of PUs (10-13) is associated with male stereotypes and that of PUs (14-20) with female ones. On the contrary, the origin of PUs (1-9), although probably lexicalized (at least in some cases) on male stereotypes, will be considered unclear.

\subsection{Corpus analysis}

The next step consists of finding out whether these PUs are really equal in terms of use and frequency in current Spanish and, what is even more important for the purpose of this study, whether they are gender-specific or not. For this reason - and inspired by the research conducted by Dobrovol'skij and Piirainen (2010) - the twenty PUs were checked against the CREA corpus of the present-day Spanish language, which contains more than 170 million words from 1975 to $2004 .^{4}$

In total, 172 documents using the 20 expressions we deal with in this paper were documented in the CREA corpus. Of course, non-figurative expressions were discarded, such as the use of "niño mimado" when referring to a spoiled child and not to an adult who behaves like one. ${ }^{5}$ Out of these 172 instances, 43 were rejected because of a lack of a satisfactory context that could undoubtedly confirm whether the $\mathrm{PU}$ in question refers to male or female individuals (metaphorical extensions denoting animals and nonhuman entities such as companies or institutions were also discarded, something which will be commented on in detail later). In this sense, the problem of gender-non-specific contexts is especially frequent among the masculine plural variants of the PUs, given that in Spanish masculine is the "unmarked gender", i.e., it is used not just for denoting a group of men, but for any set of persons including at least one man and any number of women, as, for example, in the sentence "Pero ¿qué clase de niños mimados somos? El egoísmo de las naciones es natural”, in which its author, Álvaro Fernández Suárez, refers to human beings in general, and not to a specific group of men.

In Tables 1-4 the results of the corpus analysis are shown, " $T$ " being the total number of occurrences documented, "V" the valid ones, and "M"/"F" the number of PUs exclusively referring to male/female persons. Moreover, the number of PUs with a clear positive or negative connotation in the given context is offered under "+" and "-." (note that the number of positive and negative PUs often does not agree with the total number of valid occurrences since some of them cannot be clearly evaluated as positive or negative in the sentences).

A first interesting point to consider is the absolute lack of any occurrences of five of the PUs in the corpus: Niño/a de serrano, Niño/a gótico/a, Tener pelos en los cojones (o en los huevos), Hacer un hombre, and Irse al poyetón / quedarse en el poyetón (una mujer). Moreover, three expressions are documented just once in CREA: Niño/a pitongo/a, Niño/a zangolotino/a, and Estado de merecer. Consequently, our data speak for a very sporadic use of these eight PUs in European Spanish, at least since 1975. And this even when the source of these 20 expressions is an up-to-date dictionary of contemporary Spanish.

As expected, some PUs have a masculine and a feminine version, especially those including the word niño/a. Interestingly, two of the PUs with niño/a that were aprioristically associated in this paper with the characteristics of male children are documented only with niña, although just once: Niña pitonga and Niña zangolotina. Moreover, the only PU exclusive to little girls, La niña de sus ojos, is documented once in a masculine version: El niño de sus ojos. The existence of this variant with niño in a novel from 1994, although probably inventive, would probably speak for the consolidation of a folk etymology of this PU in Spanish based on niña being exclusively understood as a little girl, in which its true origin as the pupil of the eye would have been definitively forgotten.

\footnotetext{
${ }^{4}$ See http://corpus.rae.es/creanet.html.

${ }^{5}$ For instance: "Así lo reconoce ahora la Academia Norteamericana de Pediatría al afirmar que un firme control paterno es el único modo de evitar una 'epidemia de niños mimados', luego adultos que nunca aprenderán a asumir las dificultades de la vida" (Spanish press, 1989).
} 
Table 1. Results of corpus analysis - PUs including the word niño (non-specific gender etymology)

\begin{tabular}{llcccccccc}
\hline No & PU & T & $\mathbf{V}$ & $\mathbf{M}$ & + & - & $\mathbf{F}$ & + & - \\
1 & Niño de papá & 6 & 6 & 6 & 0 & 6 & 0 & 0 & 0 \\
2 & Niño de serrano & 0 & 0 & 0 & 0 & 0 & 0 & 0 & 0 \\
3 & Niño gótico & 0 & 0 & 0 & 0 & 0 & 0 & 0 & 0 \\
4 & Niño pitongo & 0 & 0 & 0 & 0 & 0 & 0 & 0 & 0 \\
5 & Niño zangolotino & 0 & 0 & 0 & 0 & 0 & 0 & 0 & 0 \\
6 & Niño bonito & 12 & 12 & 12 & 2 & 10 & 0 & 0 & 0 \\
7 & Niño litri & 2 & 0 & 0 & 0 & 0 & 0 & 0 & 0 \\
8 & Niño mimado & 45 & 32 & 32 & 16 & 14 & 0 & 0 & 0 \\
9 & Ser (como) un niño & 14 & 11 & 11 & 0 & 9 & 0 & 0 & 0 \\
& TOTAL & $\mathbf{7 9}$ & $\mathbf{6 1}$ & $\mathbf{6 1}$ & $\mathbf{1 8}$ & $\mathbf{3 9}$ & $\mathbf{0}$ & $\mathbf{0}$ & $\mathbf{0}$ \\
\hline
\end{tabular}

In total, 79 occurrences of the word niño/niños (excluding El niño de sus ojos, since it has a clear female etymology) were documented (see Table 1). Moreover, 61 out of the total are considered valid for the purposes of this study since they make clear reference exclusively to individuals of one gender; interestingly, none of the expressions with niño refers to females. Moreover, out of the 57 PUs that can be clearly evaluated as positive or negative, 18 have a clear positive connotation (32\%) and 39 show a negative assessment (68\%). The positive uses are mainly linked to Niño mimado, a PU that has an ambiguous meaning. It can be used to denote a person who either causes trouble or, on the contrary, is venerated by some other person (or institution), as in the sentence "El valor de Schweinsteiger, niño mimado de Franz Beckenbauer, ya es legendario" (Spanish press, 2004), lit. "The value of Schweinsteiger, spoiled child of Franz Beckenbauer, is already a legend", by which it is meant that the German football player was treated especially well by his trainer.

Table 2. Results of corpus analysis - PUs including the word niña (or niño with a female etymology)

\begin{tabular}{llcccccccc}
\hline No & \multicolumn{1}{c}{ PU } & T & V & M & + & - & F & + & - \\
1 & Niña de papá & 0 & 0 & 0 & 0 & 0 & 0 & 0 & 0 \\
2 & Niña de serrano & 0 & 0 & 0 & 0 & 0 & 0 & 0 & 0 \\
3 & Niña gótica & 0 & 0 & 0 & 0 & 0 & 0 & 0 & 0 \\
4 & Niña pitonga & 1 & 1 & 0 & 0 & 0 & 1 & 0 & 1 \\
5 & Niña zangolotina & 1 & 1 & 0 & 0 & 0 & 1 & 0 & 1 \\
6 & Niña bonita & 7 & 1 & 0 & 0 & 0 & 1 & 0 & 0 \\
7 & Niña litri & 1 & 1 & 0 & 0 & 0 & 1 & 0 & 1 \\
8 & Niña mimada & 7 & 4 & 0 & 0 & 0 & 4 & 1 & 2 \\
9 & Ser (como) un niña & 5 & 5 & 0 & 0 & 0 & 5 & 0 & 2 \\
14 & a) La niña de sus ojos & 10 & 6 & 3 & 3 & 0 & 3 & 3 & 0 \\
& b) El niño de sus ojos & 1 & 1 & 1 & 1 & 0 & 0 & 0 & 0 \\
& TOTAL & $\mathbf{3 3}$ & $\mathbf{2 0}$ & $\mathbf{4}$ & $\mathbf{4}$ & $\mathbf{0}$ & $\mathbf{1 6}$ & $\mathbf{4}$ & $\mathbf{7}$ \\
\hline
\end{tabular}


On the contrary (see Table 2), instances with niña are less common in CREA - only 33 occurrences (including El niño de sus ojos, since this PU has a clear female motivation), of which 20 are considered valid. In this sense, it has to be commented that the expressions Niña mimada and Niña bonita were often considered not valid, since they frequently denote non-human references e.g library, road, orca, or aeronautics, among others. A first surprise is the expression La niña de sus ojos being used three times in its original feminine version to denote men, all of them with a positive connotation. Of the remaining 11 valid expressions with niña, 4 have a clear positive connotation, while 7 present a negative assessment. In sum, PUs including the word niña plus El niño de sus ojos are used positively 8 times $(53 \%)$ and negatively 7 times $(47 \%)$ in the CREA corpus. As a result of this, and although some of the data obtained are to some extent unexpected, it might be stated that little girls are conceptualized in a more positive way (53\% vs. $47 \%$ ) than their male counterparts (32\% vs. $68 \%$ ).

Table 3. Results of corpus analysis - PUs based on characteristics of children becoming men

\begin{tabular}{|c|c|c|c|c|c|c|c|c|c|}
\hline No & $\mathbf{P U}$ & $\mathbf{T}$ & $\mathbf{V}$ & $\mathbf{M}$ & + & - & $\mathbf{F}$ & + & - \\
\hline 10 & De pelo en pecho & 13 & 11 & 11 & 6 & 0 & 0 & 0 & 0 \\
\hline 11 & $\begin{array}{l}\text { Tener pelos en los } \\
\text { cojones (o en los } \\
\text { huevos) }\end{array}$ & 0 & 0 & 0 & 0 & 0 & 0 & 0 & 0 \\
\hline 12 & Con toda la barba & 4 & 3 & 3 & 2 & 0 & 0 & 0 & 0 \\
\hline \multirow[t]{2}{*}{13} & Hacer un hombre & 0 & 0 & 0 & 0 & 0 & 0 & 0 & 0 \\
\hline & TOTAL & 17 & 14 & 14 & 8 & $\mathbf{0}$ & $\mathbf{0}$ & $\mathbf{0}$ & $\mathbf{0}$ \\
\hline
\end{tabular}

If we now focus on PUs associated with the characteristics of people passing from childhood to adulthood, there are only 2 idioms (and 17 instances) based on male stereotypes and documented in the corpus (see Table 3). Both expressions - De pelo en pecho (11 valid instances) and Con toda la barba (3 valid instances) - are always related to men in the corpus and, when a clear evaluation can be established ( 8 instances), it is positive in all cases (100\%).

Table 4. Results of corpus analysis - PUs based on characteristics of children becoming women

\begin{tabular}{|c|c|c|c|c|c|c|c|c|c|}
\hline No & $\mathbf{P U}$ & $\mathbf{T}$ & $\mathbf{V}$ & $\mathbf{M}$ & + & - & $\mathbf{F}$ & + & - \\
\hline 15 & Edad de merecer & 19 & 15 & 3 & 0 & 0 & 12 & 2 & 1 \\
\hline 16 & Estado de merecer & 1 & 1 & 1 & 1 & 0 & 0 & 0 & 0 \\
\hline 17 & Pasársele el arroz & 4 & 0 & 0 & 0 & 0 & 0 & 0 & 0 \\
\hline 18 & $\begin{array}{l}\text { Quedarse (una mujer) } \\
\text { para vestir } \\
\text { santos/imágenes }\end{array}$ & 12 & 12 & 2 & 0 & 2 & 10 & 0 & 10 \\
\hline 19 & $\begin{array}{l}\text { Irse al poyetón / } \\
\text { quedarse en el poyetón } \\
\text { (una mujer) }\end{array}$ & 0 & 0 & 0 & 0 & 0 & 0 & 0 & 0 \\
\hline \multirow[t]{3}{*}{20} & $\begin{array}{l}\text { a) Compuesta y } \sin \\
\text { novio }\end{array}$ & 3 & 2 & 0 & 0 & 0 & 2 & 0 & 2 \\
\hline & $\begin{array}{l}\text { b) Compuesto y sin } \\
\text { novia }\end{array}$ & 4 & 4 & 4 & 0 & 4 & 0 & 0 & 0 \\
\hline & TOTAL & 43 & 34 & 10 & $\mathbf{1}$ & 6 & 24 & 2 & 13 \\
\hline
\end{tabular}


On the contrary, the situation with the 34 valid PUs based on female stereotypes is much more complicated (see Table 4). While Irse al poyetón is not documented in the corpus and logically has probably become archaic, Pasársele el arroz seems to have developed a further degree of idiomaticity. Despite showing a clear metaphorical inference - a woman that waits too long to find a husband gets ruined in the same way as rice that is boiled for too long does - the present-day use of this PU in the corpus is not restricted to the original meaning regarding women and the right time for them to get married. In fact, in their dictionary Seco et al. (2004) propose a second, more general sense of this PU: roughly, 'to be too late for something'. According to this, none of the 4 documented occurrences of this idiom is valid since each of them refers, respectively, to people in general (TV stars and politicians, both men and women), to a male dog, and to the Spanish football club Real Madrid.

On the contrary, Quedarse (una mujer) para vestir santos/imágenes, a PU with a very similar meaning, but a quite different image component, maintains its original etymology almost unchanged. So, 10 out of the 12 occurrences actually refer to a woman who stays/stayed/will stay single. In the remaining 2 cases, the person in question is a man, not a woman, but the expression is used with a clearly ironic connotation. In fact, Seco et al. (2004) rightly state in their definition of this PU that it can also humorously refer to men.

Moreover, (En) estado de merecer is documented just once and, again, ironically referring to a man (specifically to the actor Antonio Banderas). On the contrary, the almost identical PU Edad de merecer behaves rather differently. It is the second most frequent PU in the analysis, with 19 instances. 12 of the 15 valid occurrences refer to women and 3 to men. The case of these 3 male occurrences is rather specific - they all denote bullfighters and are documented in two texts belonging to the same newspaper, so that it might be plausible to presume that we are dealing here with the personal style of just one journalist. Moreover, according to the data, Edad de merecer is generally associated with a neutral connotation. There are just 2 cases in which a clear positive evaluation could be proposed, when being a woman of the "age of merit" equals being young and beautiful. On the other hand, on one occasion the connotation is rather negative.

According to Seco et al. (2004), the last PU considered in this research has both a masculine and a feminine version, Compuestalo y sin novio/a. However, the etymology of this idiom is clearly based on a female stereotype, as already mentioned.

Despite the origin of this PU, 2 valid feminine and 4 valid masculine examples are documented in the corpus. All of them present a negative connotation. However, the feminine examples denote women that in some way or another have lost a love partner - i.e. the original stereotype on which the PU is lexicalized - whilst the meaning of the masculine ones is metaphorically extended: on 2 occasions it deals with political partners, once with a driver who loses his co-driver, and, finally, the last example makes reference humorously to a man that dies without having sex.

In sum, PUs underlying the characteristics of adult men are less frequent in the corpus, but always refer to men and are evaluated positively. On the contrary, the female expressions can often denote male individuals (10 out of 34 valid occurrences, i.e., 29\%), but, in this case, it is frequent that either they are used ironically or a metaphorical extension of their meaning has occurred, so that the actual meaning of these expressions does not make reference to the original female stereotypes any more. On the contrary, when referring to women, the PUs tend to maintain their original lexicalized metaphoric semantics. Moreover, the evaluation of those PUs based on stereotypes associated with children becoming women presents an undoubtedly negative connotation -3 expressions evaluated positively (13\%) against 20 occurrences with a negative nuance (87\%). These data contrast visibly with the expressions phraseologized on the basis of adult male stereotypes, which are always positive (100\%).

\section{Data interpretation, conclusion, and representation of the passing of time}

In this paper it has been claimed that many PUs are lexicalized on the basis of stereotypes shared by an important part of a given speech community. According to this, the gender archetypes underlying the 20 PUs that have been analysed were common in earlier periods of Spanish society. The question arises whether the stereotypes they are based on are alive in contemporary Spanish society or whether they are just echoes of a more or less forgotten past. One way to shed some light on this matter is to conduct a corpus analysis that illustrates to what extent these expressions are archaic or not in Spanish and, what 
is even more important for the specific purposes of this study, if their contemporary functioning is gender-specific or not.

In this sense, a crucial question that has not received enough attention from specialists so far is that of the relationship between the frequency of use of a given PU and the endurance of the stereotypes and values underlying it. It is clear that there is no need to understand the motivation of a PU in order to employ it; in other words, speakers often make use of opaque PUs. On the other hand, people tend to reinterpret those PUs whose image component is not transparent any more by means of what is termed a folk etymology (see Dobrovol'skij and Piirainen, 2005a, p. 80ff.; 2010, p. 82). This could imply that the speakers feel the necessity of somehow understanding the PUs they use or at least feel more comfortable when these expressions are transparent. As a consequence of all this, the hypothesis could be proposed that an alive motivation - no matter if original or reinterpreted - could be a key factor regarding the endurance of PUs in time. Logically, the frequency of their use could give us some clues about the survival in the given society of the stereotypes and values included in them - again, either original or reinterpreted. ${ }^{6}$

Obviously, the data obtained for this study are far from being enough to validate or reject such an ambitious premise. However, it could be worthwhile to discuss here in some detail the case of the three PUs (17-19) that share the same sense by means of three different metaphors. Although all of them originally refer to a woman that stays single because it is too late for her to get married, the corpus analysis reveals that their contemporary functioning is very uneven. The first, Quedarse para vestir santos/imágenes (lit. "to be left for dressing saints"), is very frequent in the CREA corpus of the presentday Spanish language and maintains its original etymology almost unchanged - it denotes women that actually stay single (or men, but only sporadically and with a clearly ironic connotation). In this first case, the image component is very transparent - we can visualize a woman that assists the local priest, cleaning and taking care of the church and its statues just because she has nothing else to do (since she never married and has no husband or children). On the other hand, Pasársele el arroz a una mujer (lit. "to overcook the rice to a woman") is much less frequent in the corpus and has developed a further degree of idiomaticity, so that it is used to denote any person (not just women), or even animals or institutions for which it is too late for some specific purpose. The reason for the discrepancies in the present-day functioning of these two PUs could be found in the fact that the metaphor underlying Pasársele el arroz, although quite transparent, is much more abstract than the one present in the PU Quedarse para vestir santos/imágenes and, logically, its figurative meaning could be extended more easily. The last expression, Irse al poyetón (lit. "to go on the stone bench"), evokes a woman who sits on a bench and watches people pass by, since again she has no real duty to perform. This PU seems to be the most opaque of all three, probably since the word poyetón has become archaic. In this sense the most recent edition of the dictionary of the Royal Spanish Academy explicitly indicates that poyetón is a rare term (marked as "poco usado"), probably used in present-day Spanish exclusively in this expression, ${ }^{7}$ i.e. what is termed a "cranberry idiom" (see Makkai, 1972). Moreover, poyetón is a mere augmentative of poyete and this, at the same time, a word derived from poyo, a kind of bench present only in rural zones. ${ }^{8}$ According to this, the term poyetón is very probably unknown for a very significant part of the current Spanish population and, logically, the PU would be opaque for them. This lack of transparency could have caused a gradual process of archaization of this expression, which is probably doomed to complete disappearance from Spanish. In sum, the diverse evolution of these three expressions, which in the past probably shared a similar function, could point out that to understand the way a PU is used in contemporary language, at least three factors have to be taken into account: its etymological motivation, its image component, and its lexical component.

Apart from this tentative explanation, two more conclusive statements can be proposed in the light of the results of the analysis presented in this paper.

\footnotetext{
${ }^{6}$ In fact, in a previous work it has been claimed that sometimes speakers who use or at least know PUs involving stereotypes "significantly extend those stereotypes and attitudes beyond the linguistic spheres [and that according to this] the use of an expression could reinforce racial stereotypes (or prejudices) regarding a nation or ethnic group" (Gutiérrez Rubio 2015, p. 26).

${ }^{7}$ See http://dle.rae.es/?id=TsnGxii.

${ }^{8}$ See http://dle.rae.es/?id=Tsnl9GO.
} 
First, the main hypothesis of this study is confirmed - the notion of the passing of time is conceptualized in two different ways for women and men in Spanish phraseology. It has to be admitted that the corpus analysis presented in Section 4 has shown that the frequency of the 20 PUs analysed in this study is uneven and that many of them do not have a clear gender usage restriction. However, it has been sufficiently proved that the PUs conceptualized on the basis of characteristics associated with male children are evaluated much more negatively than those expressions related to stereotypical features of adult men. On the contrary, little girls are associated with a more positive evaluation than adult females are.

Second, the data support the statement by Dobrovol'skij and Piirainen (2010, p. 91) arguing that the etymology and the image component of a given PU can have a relevant influence on its contemporary usage. In this sense, expressions based on female stereotypes tend to preserve the negative connotation of their etymology, no matter if at the present they are used to denote male individuals. Moreover, when these PUs refer to men or any other entity (such as animals or institutions) they are inclined to develop a further degree of idiomaticity, something that does not happen (or at least not so often) when women are denoted, since in this case the PUs tend to keep closer to their etymological metaphoric semantics.

Finally, one of the aims of this paper is to propose a graphic representation of the opposite male and female conceptualizations of the passing of time in Spanish phraseology. In line with the theoretical foundations presented above (see Section 3) and data extracted from Spanish phraseology (see Section 4), two different time representations will be suggested. The first of them (Figure 2) graphically depicts the life of men as a single-line structure divided into two opposite, isolated periods - incomplete childhood and full maturity.

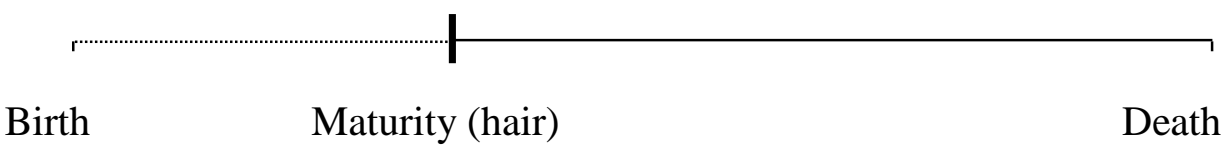

Figure 2. Representation of the male passing of time in Spanish phraseology

On the contrary, women's linear representation would look more like a continuous line, since, contrary to male conceptualization, female children and (young) women share most of their values and stereotypes. However, a short time after women leave childhood behind, the straight line becomes a "forked" path - either they find a husband, being able to fulfill their main task in life as mothers and homemakers, or they do not, ending up alone and useless to society (Figure 3).

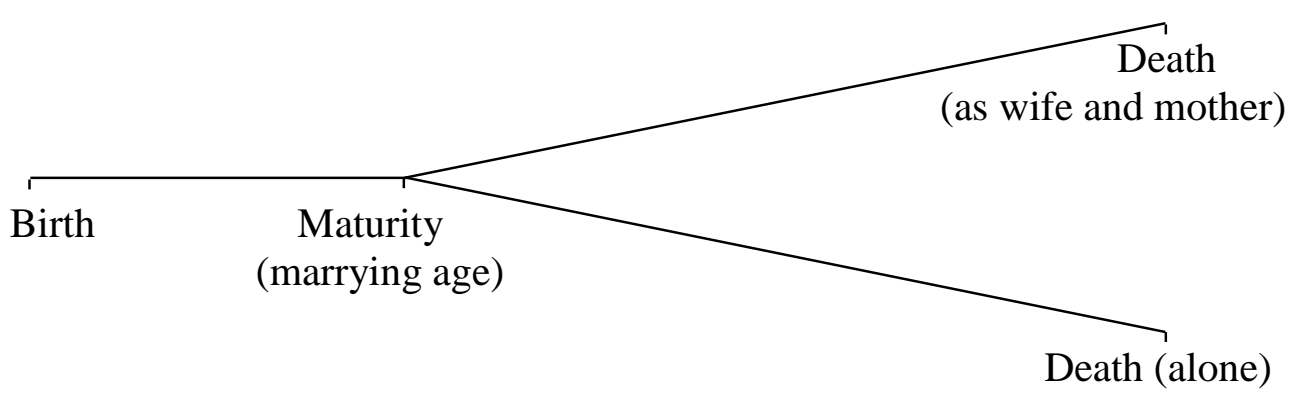

Figure 3. Representation of the female passing of time in Spanish phraseology

Obviously, the proposed linear representations are merely general schematic drafts based on scant and very fragmentary data, merely 20 PUs. However, if the capacity of phraseology for recording and preserving the relevant knowledge of a given culture is accepted, it cannot be denied that these idioms can provide us with partial but interesting information on some generalized conceptualizations regarding the gendered asymmetry of Spanish society that were shared by a significant portion of Spanish speakers in the past and, as discussed above, are, to a certain degree, still alive in the present. 
Finally, thanks to the linear representations proposed in this paper (Figures 2 and 3), the opposed conceptualizations of the passing of time for men and women in Spanish society can be graphically illustrated. By doing so, a spatial depiction of temporal events is offered, which can be useful for gaining a better understanding of such an abstract notion.

\section{Acknowledgment}

I would like to gratefully acknowledge the financial support for this research provided by the project "Romance Languages and Literatures: Between Conflict and Dialogue" (IGA_FF_2017_043).

\section{References}

Bradley, H.,2013. Gender. 2nd ed. Cambridge: Polity.

Cantera Ortiz De Urbina, J., 2011. Diccionario de dichos y expresiones del español: su interpretación al alcance de todos. Madrid: Abada editores.

Collier, R., 2004. Men, heterosexuality and the changing family. (Re)constructing fatherhood in law and social policy. In: G. Jagger and C. Wright, eds. Changing family values. London/New York: Routledge, pp. 38-58.

Connell, R. W., 2005. Masculinities. Cambridge: Polity.

Connell, R. W., 2009. Gender. In world perspective. Cambridge: Polity.

Coulson, S. and Pagán Cánovas, C., 2014. Understanding timelines: Conceptual metaphor and conceptual integration. Journal of Cognitive Semiotics, vol. 5, no. 1-2, pp. 198-219.

Dobrovol'skij, D. and Piirainen, E., 2005a. Figurative language. Amsterdam: Elsevier.

Dobrovol'skij, D. and Piirainen, E., 2005b: Cognitive theory of metaphor and idiom analysis. Jezikoslovlje, vol. 6. no. 1, 7-35.

Dobrovol'skij, D. and Piirainen, E., 2010. Idioms: Motivation and etymology. In: K. Kuiper, ed. Yearbook of phraseology 1. Berlin and New York: Mouton de Gruyter, pp. 73-96.

Doka, K. J. And Martin, T. L., 2010. Grieving beyond gender. Understanding the ways men and women mourn. New York/London: Routledge.

Doval, G., 2010. Del hecho al dicho. Madrid: Alba Libros.

Eckert, P. and McConnell-Ginet, S., 2013. Language and gender. Cambridge: Cambridge University Press.

Fauconnier, G. and Turner, M.,2008. Rethinking metaphor. In: R. W. Gibbs, ed. Cambridge handbook of metaphor and thought. New York: Cambridge University Press, pp. 53-66.

García Mouton, P., 2010. Cómo hablan las mujeres. Madrid: Arco Libros.

García Remiro, J. L., 2013, Frases con historia. Madrid: Alianza.

Grafton, A. and Rosenberg, D., 2010. Cartographies of time: A history of the timeline. New York: Princeton Architectural Press.

Gutiérrez Rubio, E., 2015. Stereotypes in Czech phraseology. Nations and ethnic groups. Topics in Linguistics, issue 16, pp.17-28.

Gutiérrez Rubio, E. ,2016. La imagen de la mujer (y del hombre) en la fraseología española. Pervivencia de los estereotipos de género en el siglo XXI. Madrid: Liceus.

Iribarren, J. M., 2013. El porqué de los dichos: sentido, origen y anécdota de dichos, modismos y frases proverbiales. Barcelona: Ariel.

Kedron, K., 2014. Genderové aspekty ve slovanské frazeologii (na materiálu běloruštiny, polštiny a češtiny). Praha: Karolinum.

Kimmel, M. S., 2011. The gendered society. Oxford: Oxford University Press.

Kövecses, Z., 2002. Metaphor: A practical introduction. Oxford: Oxford University Press.

Lakoff, G., 2006 [1993]. The contemporary theory of metaphor. In: D. Geeraerts, R. Dirven, J. R. Taylor and R. W. Langacker, eds. Cognitive linguistics: Basic readings. Berlin and New York: Mouton de Gruyter, pp. 185-238.

Lakoff, G. and Johnson, M., 1999. Philosophy in the flesh. New York: Basic Books.

Lakoff, G. and Johnson, M., 2003 [1980]. Metaphors we live by. Chicago: University of Chicago Press.

Lakoff, R., 1973. Language and woman's place. Language in Society, vol. 2, no. 1, pp. 45-80.

Makkai, A., 1972. Idiom structure in English. The Hague: Mouton.

Martín Casares, A., 2012. Antropología de género. Culturas, mitos y estereotipos sexuales. Madrid: Ediciones Cátedra. 
Mills, S., 2008. Language and sexism. Cambridge: Cambridge University Press.

Naciscione, A., 2010. Stylistic use of phraseological units in discourse. Amsterdam: John Benjamins.

Núñez, R. E., 2011. No innate number line in the human brain. Journal of Cross-Cultural Psychology, vol. 42, no. 4, pp. 651-668.

Luque Nadal, L., 2012. Principios de culturología y fraseología españolas. Frankfurt am Main: Peter Lang.

Oakley, A., 2005. The Ann Oakley reader: Gender, women and social science. University of Bristol: The Policy Press.

Pagán Cánovas, C., Valenzuela, J. and Santiago, J., 2015. Like the machete the snake: Integration of topic and vehicle in poetry comprehension reveals meaning construction processes. Psychology of Aesthetics, Creativity, and the Arts, vol. 9, no. 4, pp. 385-393.

Penadés Martínez, I., 2015. Para un diccionario de locuciones. De la lingüística teórica a la fraseología práctica. Alcalá de Henares: Universidad de Alcalá.

Piirainen, E., 2007. Phrasemes from a cultural semiotic perspective. In: H. Burger, D. Dobrovol'skij, P. Kühn, and N. R. Norrick, eds. Phraseologie. Ein internationales Handbuch der zeitgenössischen Forschung. 1. Halbband / Phraseology. An international handbook of contemporary research. Volume 1. Berlin and New York: Walter de Gruyter, pp. 208-219.

Piirainen, E., 2008. Figurative phraseology and culture. In: S. Granger and F. Meunier, eds. Phraseology. An interdisciplinary perspective. Amsterdam and Philadelphia: John Benjamins, pp. 207-228.

Seco, M., et al. 2006. Diccionario fraseológico documentado del español actual: locuciones y modismos españoles. Madrid: Santillana.

Talbot, M., 2010. Language and gender. Cambridge: Polity.

Teliya, V.,1996. Russkaja frazeologija. Semantitscheskij, pragmatitscheskij i lingvokul'turologitscheskij aspekty. Moskva: Shkola "Yazyki russkoj kultury".

\section{Appendix 1}

a capa y espada; a cuerpo de rey; a puro huevo; abogado de causas perdidas; abogado de secano; abogado del Diablo; abrirse de piernas (alguien); abrirse de piernas (una mujer); acordarse de Santa Bárbara cuando truena; al baño (de) maría (María); año(s) de Maricastaña/tiempo de Maricastaña; aparecérsele la Virgen; arrimar material (a una pers.); así se las ponían a Fernando VII; averígüelo Vargas; bailar con la más fea; bien armado/-da; bien dotado/-da; buen (o real) mozo; buen samaritano; cada uno de su padre y su madre; cagarse en su madre (en su padre); caja de Pandora; cajón de sastre; callarse como un puto; cara de juez; cara de pepona; casa de putas; casar(se) por el sindicato de las prisas; casarse de penalti; caza de brujas; ciento y la madre; colgar los hábitos; comer el coño; comer el chocho (a una mujer); comer la polla; comerse una rosca; como don Tancredo; como la madre que lo parió; como Mateo con la guitarra; como Pedro por su casa; como Perico por su casa; como puta por rastrojo; como putas en cuaresma; como si se la machaca; como un anacoreta; como un carretero; como un figurín; como un Judas; como un maharajá; como un marqués; como un novio; como un patriarca; como un pepe; como un príncipe (hecho un príncipe); como un/a rey/reina; como un sacamuelas; como un señor; como un señorito; como un sultán; como un tren/para parar un tren; como una bruja/más que una bruja; como una Dolorosa; como una Magdalena; como una pepona; como una ursulina; como una verdulera; compuesta y sin novio/compuesto y sin novia; con dos cojones; con pólvora ajena (del rey); con toda la barba; con un par de cojones/huevos/pelotas; conceder la mano (de una mujer a un hombre); conocer mujer; conocer varón; contra natura; correrse una barba; corta, Blas, que no me vas; cortársela; costar un huevo/un huevo y medio; criar (una mujer a alguien) a sus pechos; cuando Fernando VII gastaba paletó; cuando San Juan baje el dedo; cuéntaselo a tu abuela/se lo cuentas a tu abuela; cuéntaselo a tu tía; cuéntaselo a un guardia; cueva de ladrones; chupársela (a un hombre); dar (alguien) palabra (de caballero); dar a luz; dar el braguetazo; dar el coñazo; dar el pecho (una mujer a alguien); dar la teta (a un niño); dar tres cuartos al pregonero; dar un revolcón; darle calentón (a alguien); darse el calentón; de (entre) caballeros; de bigote(/s); de bombero; de cojón (de pato o de mico); de cojones (o de tres pares de cojones); de flor en flor; de Herodes a Pilatos; de hombre a hombre; de la acera de frente; de las pelotas; de los cojones; de mujer a mujer; de padre y muy señor mío; de pelo en pecho; de pelotas; de propia minerva; de psiquiatra; de puta madre; derecho de pernada; descender de la pata del Cid; desertor del arado; Dios y su madre/y su padre; doctores tienen la (Santa Madre) Iglesia; dolor de viudo; don Juan; donde dije digo, digo Diego; dos huevos; dos pelotas; dueño y señor; echar un casquete; edad de 
merecer; el cuento de la lechera; el eterno femenino; el hijo de mi madre (de mi padre); el hombre de la calle; el hombre del saco; el huevo de Colón; el oficio más viejo del mundo; el parto de los montes; el Preste Juan (de las Indias); el quinto coño; el rey de la creación; el rey de Roma; el rey del mambo; elemental, querido Watson; en estado; en sus propias (mismas) barbas; entre caballeros; eres mi padre; (eso) será lo que tase un sastre; estado de merecer; estar (un hombre) para hacerle padre; estar/quedarse en bragas; estar cañón; estar de rodríguez; estar hasta los mismos (cojones); fe del carbonero; hacer (a alguien) la picha un lío; hacer a pelo y (a) pluma; hacer chapas; hacer el amor; hacer fuentes; hacer la calle; hacer la carrera; hacer la(s) acera(s); hacer mujer (a una virgen); hacer un bombo; hacer un hijo; hacer un hombre; hacer una paja; hacer vida marital; hacerse el Lorenzo; hasta el coño; hasta el moño; hasta el Tato; hasta las pelotas; hasta los cojones; hasta los huevos; hasta los ovarios; hecho un adán/como un adán; hecho un nazareno; hijo de la Gran Bretaña; hijo de la gran puta; hijo de papá (de familia); hijo de puta; hijo de puta/perra/su madre/mala madre/Satanás/la grandísima; hinchar las pelotas/huevos/ cojones; hinchársele a alguien las pelotas/ huevos/cojones; hombre de armas; hombre de la casa; hombre de paja; hombre de su casa; hombría de bien; importar (algo a alguien) tres pelotas/huevos/ cojones; irse al poyetón / quedarse en el poyetón; Juan Lanas; Juan Palomo; jugador de ventaja; jugarse el bigote; jurar por mi madre/padre; la acera de frente/la otra acera; la gran vida/la vida padre; la jodimos, tía Paca (tía María); la madre del cordero; la niña de sus ojos; la purga de Benito; la reina de los mares; ladrón/-na de guante blanco; lanzar el guante (a alguien); las bodas de Camacho; las de Caín; le digo a usted, señor guardia; ley de Murphy; ligero de cascos; lo dijo Blas, punto redondo; lo que ve la suegra; los (señores) del margen; los cojones; los polvos de la madre Celestina; llevar (a alguien) a la silla de la reina; llevar los pantalones bien puestos; llevarse a la cama; machacársela; madre de alquiler; madre de leche; madre mía (madre de Dios); madre mía (madre santísima); madre patria; mala mujer; mamarla; manda cojones; marcar paquete; más (maricón) que un palomo cojo; más desgraciado que el Pupas; más feo que pegarle a un padre; más feo que Picio; más galán que Mingo; más hambre que un maestro de escuela; más listo que Briján; más listo que Cardona; más papista que el Papa; más puta que las gallinas; más que Carracuca; más que el palo de un churrero; más tonto que Abundio; más tonto que Pichote; más viejo que Matusalén; matar al mensajero; me cago en tu madre (en tu padre; en tus muertos); me la chupas; me la refanfinfla; medio hombre; meneársela (alguien a un hombre); mentar (a) madre; mentir por (la) mitad de la barba; meterla; meterse a farolero (alguien); meterse a redentor/-ra; metérsela; mi santo; mojar (en) caliente; mover el bigote; moza de fortuna (del partido); mujer de la calle; mujer de la vida/de vida alegre; mujer de precio; mujer de su casa; nacido de madre; ni cojones; ni el Tato; ni la madre que lo parió; ni su padre; niño bonito; niño de papá; niño de Serrano; niño gótico; niño litri; niño mimado; niño pitongo/bitongo; niño zangolotino; no casarse ni con su padre; no contar con la huéspeda; no haber (no quedar/no tener) más huevos; no haber más (no quedar/no tener) cojones; no hay tío páseme usted el río; no hay tu tía; no te enrolles, Charles Boyer; no tener/necesitar abuela; no tener padre (alguien) padre ni madre ni perro (o perrito) que le ladre; objetor de conciencia; ole/ olé tus huevos/pelotas/cojones; padre conscripto; padre de alquiler; padre de la patria; Palomo cojo; pantalón de montar; para que te vayas con los soldados; pasarlas putas; pasarlo teta; pasarse (alguien algo) por los huevos/pelotas/cojones; pasársele el arroz (a una mujer); pedir la mano; pedir pelea (una mujer); pegársele el arroz (a una mujer); pelársela (a un hombre); pelos de bruja; pellizco de monja; Perico el de los palotes; pillar cacho; poner las pelotas encima de la mesa; poner los huevos/pelotas/ cojones encima de la mesa; poner rabos (o un rabo); ponerse como el Quico; ponerse como un pepe; ponerse los pantalones; ponerse moños; ponérsele (algo a un hombre) en la punta del nabo (de la polla); por barba; por huevos/pelotas/cojones; por los cojones; príncipe azul (encantado); putón verbenero (desorejado); qué cojones; qué coño; qué pelotas; qué risa, tía Felisa, quedar como un cochero; quedarse (una mujer) para vestir santos; quedarse para vestir imágenes; rascarse los huevos; real hembra; Rita la cantaora; saber más que Lepe; sacar de madre; salir del coño/chocho (algo a una mujer); salir(se) de madre; salirle (algo a alguien) de las pelotas/huevos/ cojones; salirle (algo a un hombre) de la punta del nabo (de la polla); salirle de los ovarios; santo varón; ser (algo) como tener un tío en Alcalá; ser (algo) Juan y Manuela; ser (algo) puñalada de pícaro; ser (alguien o algo) la carabina de Ambrosio; ser hombre (con una mujer); ser hombre (para algo); ser madre; ser moza; ser mujer (una jovencita); ser padre; ser profeta en su tierra; ser un niño; sexo femenino (débil/bello); sexo masculino (fuerte/feo); soplar (a alguien) la musa; su abuela/tu abuela; su madre; su padre (tu padre); sudar el chocho; sudársela; suplicio de Tántalo; tener (alguien a un hombre) cogido por los huevos/pelotas/cojones; tener (una mujer) los ovarios bien puestos; tener bigotes; tener huevos (tener los huevos 
bien puestos); tener las pelotas bien puestas; tener más cuento que Calleja; tener pelos en los cojones; tener pelotas (algo); tener pluma; tener un polvo (estar para un polvo); tener un revolcón; tenerlos bien puestos (un hombre); tiempos de Maricastaña; tío bueno; tío de América; tirar de la oreja a Jorge; tirar los tejos (a alguien); tocar las pelotas/huevos/cojones; tocarse las pelotas/huevos/cojones; tócate las pelotas; tócate los huevos (manda huevos); tomar (a alguien) por el pito del sereno; un cojón; un par de ovarios; venir el tío Paco con la rebaja; verdad de Pero Grullo/ Perogrullo; viejo verde; y lo que te rondaré; (morena); yo que tú no lo haría, forastero. 